\title{
THE CHALLENGES \& OPPORTUNITIES OF E-VERIFICATION AND E- VOTING ON SIMULTANEOUS VILLAGE HEAD ELECTIONS (PILKADES) IN PEMALANG REGENCY IN 2018
}

\author{
Susanti $^{\mathrm{a}}$, Siti Aisyah ${ }^{\mathrm{b}}$, Mani Festati Broto ${ }^{\mathrm{c}}$, Made Yudhi Setiani ${ }^{\mathrm{d}}$ \\ ${ }^{a, b, c, d}$ Universitas Terbuka, Jl.Cabe Raya-Pondok Cabe-Pamulang, Tangsel, Indonesia \\ susanti@ecampus.ut.ac.id
}

\begin{abstract}
Pemalang Regency is one regent first trial national who establish e-verification and evoting on Pilkades simultaneously and in 2018 in 172 villages. Method observation during the pilkades found that with e-ID card e-verification followed e-voting in practice is strongly influenced by use of technology local electronic based and networks. This study found several challenges influence the pilkades simultaneously in Pemalang Regency 2018 years, namely a lack of socialization and simulation government, unpreparedness the community, community limited infrastructure and support. The lack of socialization resulted in the process e-verification and e-voting in this when no pilkades with different pilkades that uses paper ballots, the difference the result is issued rapidly as pilkades after. Unpreparedness the community in Pilkades for $55 \%$ of 50 over years old still stutter technology, thus the voters from outside to guide chambered sound. Unstable electricity to every village has to provide generator, and the effectiveness of the moment the networks operate generator power lines fell deeply affect the smoothness of Pilkades. Because there needs to be cooperation with the stakeholders: the local government, the voters, the committee/Pilkades officers, BPPT and PT. INTI as developing technology, and PLN. In terms of chances, the Pilkades simultaneously in Pemalang Regency in 2018 has found that accuracy and speed the Pilkades, the efficiency of the funds and the time, the integrity of the committee, elector of the privacy of the voting booth well maintained. It means operational the contraints to be covered by the integrity committee/officers and security system of keeping the votes voters behind the voting booth.
\end{abstract}

Keywords: e-verificaton, e-voting, networks, integrity, and the security system. 


\section{Introduction}

The election of village heads is regulated in Law Number 6 of 2014 concerning Villages, where in Article 25 and 26 of Law Number 6 Year 2014 and Regulation of the Minister of Home Affairs (Permendagri) Number 112 of 2014 concerning Pilkades Article 33 Paragraph (2).

Residents who have the right to vote come to the polling station (TPS) during the Pilkades, enter the voting booth and make an election by casting one of the candidates (picture mark) in the ballot to then put it in the ballot box. Along with the development of science and technology innovation was born in democracy. The use of electronicverification (e-verification) and electronic-voting (e-voting) penetrated the village democratic process, so voters no longer need to cast paper-based images in the electoral booth. E-verification is a method of identifying the use of suffrage using fingerprints and electronic ID cards as a single identity (NIK). The officer will check the KTP-el and match the voter NIK as verification. Darmawan et al. (2014: 2) interpreting e-voting as "the use of suffrage in the election by using electronic technology assistance". The emphasis on this method of voting must be followed by aspects of the use of suffrage. The use of electronic technology according to Kersting and Baldersheim (2004: 5) includes when registering, the election process, counting, including facilitating voters remotely through internet voting. Furthermore the paper Centikaya \& Centikaya (2007) reveals that "e-voting refers to the use of computers or computerises voting equipment to cast ballots in election". This means that e-voting refers to computerization of equipment in elections. Thus it can be said that e-verification and e-voting in the discussion of this paper will refer to Kersting and Baldersheim (2004) and Centikaya \& Centikaya, namely the method of voting with the help of electronic technology devices for registration and selection process based on single identity.

The adoption of e-pilkades technological innovations (e-voting and everification) in Indonesia has been implemented in 981 village head elections in 18 districts, 11 provinces (Source: Community Empowerment and Village Government Service (Dispermasdes) of Pemalang District; October 24, 2018). The following are data on the use of e-Pilkades technology innovation as follows.

Table 1. Data on Regency and Number of Villages that Have Implemented ePilkades 
Proceeding ICOGISS 2019

Page 414-422. ISBN: 978-602-6 988-75-1

Web Jurnal Online: jurnal.unmuhjember.ac.id

By: Susanti; Siti Aisyah; Mani Festati Broto; Made Yudhi Setiani

The Challenges \& Opportunities of E-verification and E-voting on Simultaneous Village

Head Elections (Pilkades) in Pemalang Regency in 2018

\begin{tabular}{|c|c|c|c|}
\hline No. & Year & Regency & $\sum$ Villages \\
\hline \multirow{4}{*}{1.} & \multirow{4}{*}{2013} & Focus: e-voting & 11 \\
\hline & & Boyolali & 7 \\
\hline & & Jembrana & 2 \\
\hline & & Musi Rawas & 2 \\
\hline \multirow[t]{2}{*}{2.} & \multirow[t]{2}{*}{2014} & Focus: e-voting & 95 \\
\hline & & Musi Rawas & 95 \\
\hline \multirow[t]{5}{*}{3.} & \multirow[t]{5}{*}{2015} & $\begin{array}{l}\text { Focus: e-voting with technology transfer to PT. INTI, } \\
\text { Boalemo (plus e-verification). }\end{array}$ & 300 \\
\hline & & Empat Lawang & 101 \\
\hline & & Bantaeng & 9 \\
\hline & & Bayuasin & 160 \\
\hline & & Boalemo & 30 \\
\hline \multirow[t]{5}{*}{4.} & \multirow[t]{5}{*}{2016} & Focus: e-voting \& e-verification & 117 \\
\hline & & Batang Hari & 32 \\
\hline & & Pemalang & 11 \\
\hline & & Musi Rawas & 58 \\
\hline & & Boyolali & 16 \\
\hline \multirow[t]{10}{*}{5.} & \multirow[t]{10}{*}{2017} & Focus: Regional Head Election (Pilkada) Miniature & 161 \\
\hline & & Bogor & 1 \\
\hline & & Mempawah & 20 \\
\hline & & Agam & 28 \\
\hline & & Boyolali & 5 \\
\hline & & Bantaeng & 25 \\
\hline & & Banyuasin & 48 \\
\hline & & Boalemo & 17 \\
\hline & & Indragiri Hulu & 1 \\
\hline & & Musi Rawas & 16 \\
\hline \multirow[t]{10}{*}{6.} & \multirow[t]{10}{*}{2018} & Focus: Strengthening Election Disputes with Technology & 297 \\
\hline & & Sidoarjo & 14 \\
\hline & & Sarolangun & 39 \\
\hline & & Pemalang & 172 \\
\hline & & Batanghari & 15 \\
\hline & & Luwu Utara & 3 \\
\hline & & Mempawah & 10 \\
\hline & & Bogor & 1 \\
\hline & & Ogan Komering Ulu Timur & 40 \\
\hline & & Pasaman Barat & 3 \\
\hline & & $\Sigma$ Villages & 981 \\
\hline
\end{tabular}

(Source: Community Empowerment and Village Government Service (Dispermasdes) of Pemalang Regency; October 24, 2018).

The table shows the use of KTP-el as a basis for E-voting and E-verification has also been developed. Pemalang District is very attractive because in 2018 it was one of the districts in Indonesia that implemented simultaneous e-voting and e-verification in 172 of 211 villages (82\%) administering Pilkades.

Implementation of e-verification \& e-Voting in simultaneous Pilkades in Pemalang Regency in 2018 is a challenge as well as an opportunity for Pemalang District in applying innovation technology for democracy. Through observation in the field during the Pilkades period, interviews and documentation; and using the framework of the IDEA (Institute for Democracy and Electoral Assistance) e-voting system which categorizes e-voting (include e-verification) in four types, namely (International IDEA, 2011:44): (1) Direct recording electronic or DRE, (2) Optical Mark Recognition System ( OMR), (3) Electronic Ballot Printer or EBP), and (4) Selection system through internet or internet voting, so conclusions can be drawn at the end of the paper. Thus this paper is 
Page 414-422. ISBN: 978-602-6 988-75-1

Web Jurnal Online: jurnal.unmuhjember.ac.id

By: Susanti; Siti Aisyah; Mani Festati Broto; Made Yudhi Setiani The Challenges \& Opportunities of E-verification and E-voting on Simultaneous Village Head Elections (Pilkades) in Pemalang Regency in 2018

expected to provide input for policy makers in implementing e-democracy if it will be applied in other villages or broader levels (districts/cities or provinces) as well as finding solutions to close the weaknesses of e-democracy.

\subsection{E-Verification \& E-Voting Challenges In Simultaneous Pilkades}

Based on the Pemalang District Head Decree Number 141.1/386/2018 concerning the Implementation of Voting in the Simultaneous Village Head Election in Pemalang District Year 2018; Pilkades is carried out in stages as many as ten (10) waves, namely as follows.

Table 2. Implementation Date of Pilkades and Village Implementing

\begin{tabular}{|c|c|c|c|}
\hline No. & Waves to \& Date & $\begin{array}{l}\text { Sub District } \\
\text { (Kecamatan) }\end{array}$ & $\begin{array}{l}\sum \text { Villages that Implement } \\
\text { Pilkades }\end{array}$ \\
\hline \multirow[t]{3}{*}{1} & \multirow{3}{*}{ I - September 2, 2018} & Taman & 16 \\
\hline & & Petarukan & 2 \\
\hline & & $\sum$ Villages & 18 \\
\hline \multirow[t]{4}{*}{2} & \multirow[t]{4}{*}{ II - September 9, 2018} & Watukumpul & 11 \\
\hline & & Belik & 6 \\
\hline & & Bodeh & 1 \\
\hline & & $\sum$ Villages & $\mathbf{1 8}$ \\
\hline \multirow[t]{3}{*}{3} & \multirow[t]{3}{*}{ III - September 16, 2018} & Bantar Bolang & 9 \\
\hline & & Randu Dongkal & 7 \\
\hline & & $\sum$ Villages & 16 \\
\hline \multirow[t]{4}{*}{4} & \multirow[t]{4}{*}{ IV -September 23, 2018} & Pemalang & 12 \\
\hline & & Bantar Bolang & 1 \\
\hline & & Randu Dongkal & 1 \\
\hline & & $\sum$ Villages & 14 \\
\hline \multirow[t]{3}{*}{5} & \multirow[t]{3}{*}{ V-September 30,2018} & Bodeh & 12 \\
\hline & & Ampel Gading & 6 \\
\hline & & $\sum$ Villages & $\mathbf{1 8}$ \\
\hline \multirow[t]{4}{*}{6} & \multirow[t]{4}{*}{ VI - Oktober 7, 2018} & Belik & 1 \\
\hline & & Pulosari & 8 \\
\hline & & Moga & 9 \\
\hline & & $\sum$ Villages & $\mathbf{1 8}$ \\
\hline \multirow[t]{5}{*}{7} & \multirow[t]{5}{*}{ VII - Oktober 14, 2018} & Petarukan & 14 \\
\hline & & Ulujami & 1 \\
\hline & & Comal & 1 \\
\hline & & Ampel Gading & 2 \\
\hline & & $\sum$ Villages & 18 \\
\hline \multirow[t]{3}{*}{8} & \multirow[t]{3}{*}{ VIII- Oktober 21, 2018} & Ulujami & 14 \\
\hline & & Comal & 4 \\
\hline & & $\sum$ Villages & $\mathbf{1 8}$ \\
\hline \multirow[t]{4}{*}{9} & \multirow[t]{4}{*}{ IX - Oktober 28, 2018} & Comal & 11 \\
\hline & & Bodeh & 2 \\
\hline & & Ampel Gading & 5 \\
\hline & & $\sum$ Villages & $\mathbf{1 8}$ \\
\hline \multirow[t]{5}{*}{10} & \multirow[t]{5}{*}{$\mathrm{X}$ - November 4,2018} & Randu Dongkal & 8 \\
\hline & & Warungpring & 5 \\
\hline & & Belik & 2 \\
\hline & & Moga & 1 \\
\hline & & $\sum$ Villages & 16 \\
\hline \multicolumn{3}{|c|}{$\begin{array}{l}\text { In total the Village of Pilkades Pemalang Regency in } \\
2018\end{array}$} & 172 \\
\hline
\end{tabular}

There is a set of devices used in e-verification and e-voting consisting of five tools, namely: (1) a special computer is used to display the Permanent Voters List (DPT). The inputted DPT is data that is verified and originates from the Pilkades committee; (2) KTP Reader is a KTP-el reader. Its function is to read population data of citizens who want to fulfill their voting rights; (3) Access openers in the form of plastic cards (smart cards) such as ATMs containing digital data. There is a password for voters to enter the e- 
voting system; (4) Computer generators equipped with touch screen computer monitors with candidates in the voting booth. There is also a feature to repeat if the choice is to be replaced or abstention; (5) Thermal printers, namely a choice of paper printer. Without voter identity, this receipt paper is included in the Audit Box to be collected, stored and guaranteed confidentiality. This Audit Box is only opened if a dispute occurs.
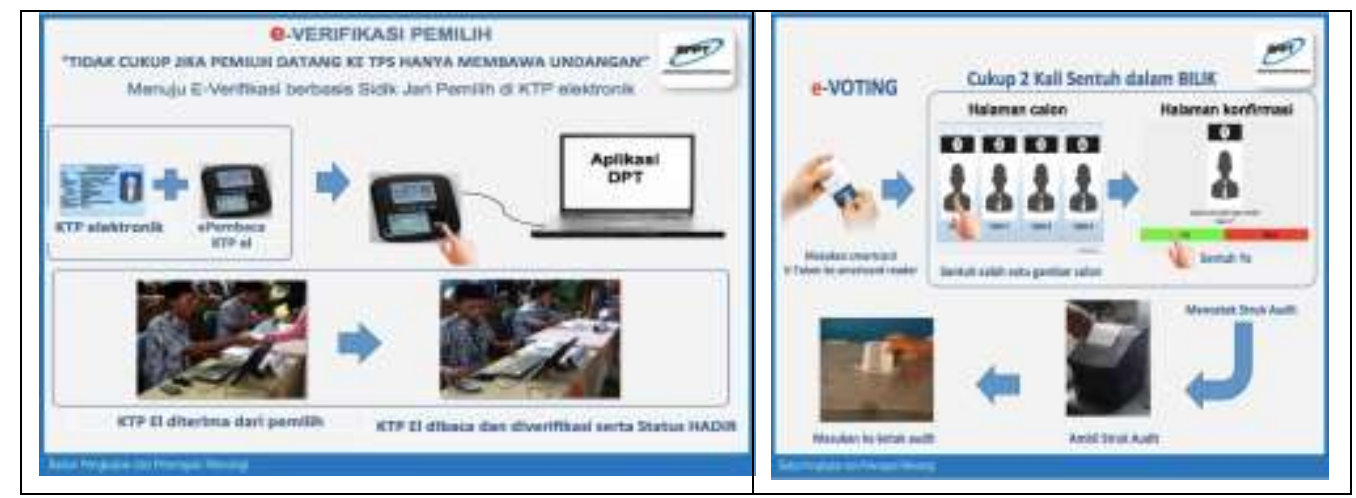

Figure 1. Voter e-verification and e-voting

Source: https://ptik.bppt.go.id/berita-ptik/73-e-pilkades-sarolangun-30-juli-2018.

The e-verification stage is matching the fingerprint of voters with single identity in a program that has been inputted by the DPT by the Pilkades Committee. The KTP-el that is affixed and fingerprinted, the voters, then the NIK can be known and its existence can be quickly tracked in the DPT. The main key is in fingerprints and KTP-el, so that at this stage it went smoothly, except in Sitemu Village running smoothly. This is due to lack of skilled officers in the field so that by informant $\mathrm{X}$ it is said that there is no verification of voters. In addition, the obstacles faced by officers in e-verification are: if the KTP-el brought by the voter is not read by the card reader. If the KTP-el is damaged, then verify with the NIK entry manually and the corresponding KTP data appears to identify the electronic DPT. Dissemination of the implementation of the Village Headquarters was carried out by Dinpermasdes Pemalang Regency to Local Government Organizations (OPD), leaders, village officials, sub-district and village level committees, Main Technical Staff (TTU)/ Field Technical Staff (TTL) and to the community.

OPD supervises with TTU/TTL to the community, culminating at Day-1 (rehearsal/ simulation). But in fact when the rehearsal was attended by only about $50 \%$ of the voters, it was not on time and the attitudinal attitude accompanied by shame made the simulation of rehearsal less optimal. It is best for the committee to identify and prioritize people who are clueless and those above 50 years of age as the first priority that must be present at the rehearsal. Therefore, in the future socialization with stakeholders needs to be built well and continuously, so that an attitude of embarrassment to ask questions and fear of trying at the time of simulation can be reduced so that the time needed for Pilkades can be faster. A set of devices can facilitate around 300 voters; so that if the number of voters is large then several sets of devices must be provided. The government also provides a set of backup devices for each village that implements Pilkades with the aim that if there is one that does not function, it can immediately be handled. Considering the 
electricity network is not stable, then for preparation and anticipation if the electricity goes out, generator sets should be available in each village. The case that occurred in Pemalang, the power grid died during the pilkades, demanding that the generator set be turned on. However, because there were no previous trials, the generator could not be turned on so that residents and officers had to wait for the electricity to start until 8:00 p.m. Regarding the electricity constraints, in fact Dinpermasdes (Community Empowerment Service and Village Government) has held a coordination meeting with agencies or related agencies, including the National Electric Company to prevent power outages when the pilkades take place. So PLN also already knows the information on the implementation of the pilkades. Thus, the non-technical constraints in the implementation of pilkades are a challenge.

For some voters over the age of 50 and stuttering technology, it is an obstacle when the concerned person enters the voting booth. Need help from outside the voting booth to guide until the ballot paper is printed. Informer Y.A. one of the witnesses from Sokawangi Village revealed that this situation was often used by the Committee which was not neutral to direct voters, so that it was not in accordance with overflowing principles. Therefore, the neutrality of the Pilkades Committee needs to be taken into account, and there are still village officials who are involved or become the success team of the Pilkada even though they are secretly. Because the neutrality factor of the Pilkades Committee, village officials, and the government must be the main concern and need to be given strict sanctions. The absence of strict sanctions makes the public less appreciative of the applicable legal norms in the implementation of Pilkades.

After the e-voting is closed, the results of electronic voting can be obtained. The results of this quick recapitulation calculation or e-recapitulation. After the results of the vote count calculation of the polling station are printed, and the $\mathrm{C} 1$ plano form is affixed with electronic signatures KPPS; then these legally valid electronic documents can be sent directly from the polling station to the data center and recapitulated automatically and tiered starting from the village, sub-district, district. Thus, during the selection process, the BPPT e-voting system is not connected to the internet network or other computer networks so that it does not allow hackers to enter the system and change the sound data. However, an audit of a tool or software is required before implementation. First: however, pragmatism can also be an obstacle to e-voting through internal or external hacking. Second, it is possible to leak data about individual choices. Therefore, ethics need to be upheld by all interested parties, especially the audit so that the software is used as intended. Thus e-verification and e-voting will have an impact on e-counting and e-recapitulation from a faster time side. While in terms of data leakage, an audit of public institutions is needed before and after implementation in a transparent manner and involves citizen participation.

\subsection{E-Verification \& E-Voting Opportunities In Simultaneous Pilkades}

Technological progress opens opportunities for efficiency; but also demands a better quality of democracy. E-democracy demands integrity in a comprehensive manner from stakeholders. In terms of government, it is required to continue to develop e- 
democracy technology in a proven manner, and free from interests. Therefore, ethical factors become a major factor before this opportunity is implemented. If so far, a set of evoting tools with only a maximum capacity of 300 people must continue to be improved. In terms of the human resources of the apparatus, the neutrality must also be maintained, as well as the committee involved must be neutral. Because the facts show that the committee's neutrality is difficult to enforce in the field. In terms of implementation, the government was also demanded for at least six months the implementation of the local election began to carry out socialization of the tools to voters. This is important for citizens to familiarize the use of e-democracy tools so that they can reduce the role of officers in guiding voters from outside the voting booths. As Noveck (Gibson, etc., 2004: 44) puts it: "It is not technology per which is either fostered or denigrates the connection between communications media and participatory democratic culture. Technology exists within a framework of values and ideals, both inherent to it and imposed by the external legal and institutional structures".

E-democracy technology also provides an opportunity for citizen political participation as consumer e-democracy not to choose existing choices or abstain. This means that technology can accommodate the desire of citizens to abstain. But what needs to be observed is between the choice and printed receipt paper must be appropriate. Because this is a factor of data accuracy. Audit box that is not opened at TPS, means that the software tool must be accurate. Therefore the audit of software tools must involve the participation of local residents, and demand citizen supervision of the software. Finally, stakeholders' ethical factors, neutrality of interests, modernity of e-democracy tools play an important role so that e-democracy can be implemented in a wider scope. What is clear is that there is a need for ongoing trials and evaluations to achieve a perfect e-democracy.

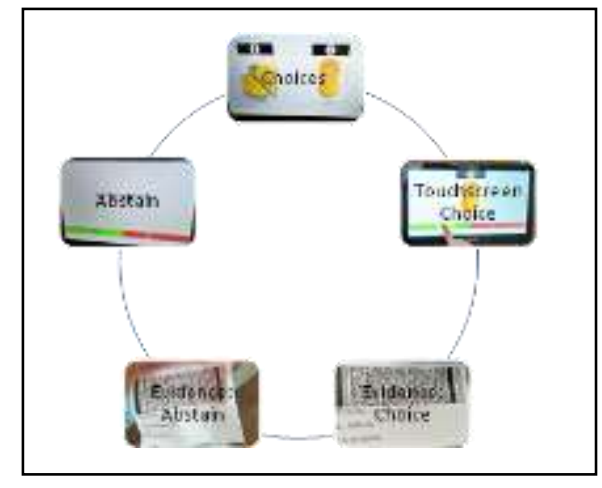

Figure 2: Examples of Selected Forms in Kandang Village, Comal Sub-District, Pemalang;14102019.

International IDEA (2011: 6) categorizes e-voting in 4 types, namely: (1) direct recording electronic (DRE), (2) Optical Mark Recognition System (OMR), (3) Electronic Ballot Printer or EBP), and (4) Selection system through the internet or internet voting. Referring to the International IDEA category, the pilkades in Pemalang Districat can be analyzed as follows. First, the Pilkades has used a voting machine with electronic direct 
recording (DRE) accompanied by evidence in the form of receipt paper that is included in the audit box by voters. Computer technology used using touch screens.

Second, the OMR system is based on a scanning machine. The advantages of this data make it easier for the vote counting system because of the existence of a scanning machine. The disadvantage is that e-democracy is easily misused. Third, the sound printing machine (EBP) is the same as the DRE so as to produce sound proof print out. This facilitates automatic counting of sounds. Fourth, the voting system through internet voting. Voting in Pilkades in Pemalang is given through computers connected to the local server, even though the final report from the KPPS at the polling station already uses network technology for e-recapitulation reported in stages (village-district-district). The use of the internet is limited to recording data and reporting the results of recapitulation. In the future, internet voting needs to be developed with optimal supervision, so that the people who choose are confirmed to be the right people concerned. Things that are somewhat different from the facts in the field, regarding unreadable KTP-el data, it is necessary to add the fifth category to overcome the impasse of e-democracy. Fifth is a manual system for bridging voters using suffrage through key in to open the data through input officers. This fifth alternative must be sought at a minimum while reducing edemocracy fraud.

\section{Conclusion}

The challenges \& opportunities of e-verification and e-voting on simultaneous village head elections (Pilkades) ini Pemalang Regency concerns technical and nontechnical factors. Technical factors include socialization by the government that is not optimal because of: the limited skills of the committee using tools, the absence of residents in socialization, the culture of shame in asking and trying tools. Non-technical factors related to the readiness of tools, such as: limited generator set, KTP-el which is not readable by smart cards. In terms of opportunities, technical and non-technical improvements must be followed by the neutrality of stakeholders, democratic ethics upheld by stakeholders, tools or software that are accurate and continuously audited transparently and involve citizens, as well as the need for citizen supervision in implementing e-democracy as a form of participation citizen. The implementation of pilkades in Pemalang Regency conceptually gave birth to the 5th type of e-voting system from International IDEA which aims to bridge conventional technology with edemocracy. 
Page 414-422. ISBN: 978-602-6 988-75-1

Web Jurnal Online: jurnal.unmuhjember.ac.id

By: Susanti; Siti Aisyah; Mani Festati Broto; Made Yudhi Setiani

The Challenges \& Opportunities of E-verification and E-voting on Simultaneous Village Head Elections (Pilkades) in Pemalang Regency in 2018

\section{References}

Centikaya, O., \& D. Centikaya. 2007. Verification and Validation Issues in Electronic Voting. The Election Journal of e-Government. Vol. 5 Issue 2 (117-126). Retrieved from www.ejeg.com/issue/download.html?idArticle $=94$

Darmawan, I., Nurhandjati, N., Katini, E. 2014. Memahami E-Voting: Berkaca dari Pengalaman Negara-negara lain dan Jembrana (Bali). Jakarta: Pustaka Obor Indonesia.

International IDEA. 2011. Introductiong Electronic Voting: Essential Considerations. Stockholm: International IDEA.

Gibson,R.K., Rommele, A., Ward, S.J. 2004. Electronic Democracy: Mobilisation, organisation and participation via new ICTs. London and New York: Routledge.

Kersting, N. \& Baldersheim, H. (Ed). 2004. Electronic VotingandDemocracy: A Comparative Analysis. New York: Palgrave Macmillan.

Undang-Undang Republik Indonesia No. 6 Tahun 2014 Tentang Desa. Lembaran Negara RI 15 Januari2014.

Permendagri No. 112 Tahun 2014 tentang Pilkades.

Voter e-verification and e-voting, https://ptik.bppt.go.id/berita-ptik/73-e-pilkadessarolangun-30-juli-2018 